\title{
Lipase-producing Filamentous Fungi from Non-dairy Creamer Industrial Waste
}

\author{
Desty Triyaswati and Miftahul IImi* \\ Faculty of Biology, Universitas Gadjah Mada, Jl. Teknika Selatan, Sekip Utara, Yogyakarta 55281, Indonesia
}

Received: December 23, 2019 / Revised: February 14, 2020 / Accepted: February 17, 2020

\begin{abstract}
Lipase-producing fungi have been isolated from environments containing lipids. The non-dairy creamer industrial waste has a high amount of lipids so it is a potential source for the isolation of lipase-producing fungi. However, the study of fungi that secrete lipase from this industrial waste has not been reported. The purpose of this study was to obtain lipase-producing filamentous fungi from non-dairy creamer industrial waste. Mineral salt and potato dextrose agar were used as media for the isolation process. The qualitative screening was conducted using phenol red agar medium and the quantitative screening using broth medium containing glucose and olive oil. Isolates producing the highest amounts of lipase were identified with molecular methods. We found that 5 out of 19 isolated filamentous fungi are lipase producers. Further analysis showed that isolate Ms.11 produced the highest amount of lipase compared to others. Based on ITS sequence Ms.11 was identified as Aspergillus aculeatus. The lipase activity in medium containing $1 \%$ glucose $+1 \%$ olive oil at $\mathrm{pH} 7.0$ and $30^{\circ} \mathrm{C}$ after 96 and $120 \mathrm{~h}$ of incubation was $5.13 \pm 0.30 \mathrm{U} / \mathrm{ml}$ and $5.22 \pm 0.59$ $\mathrm{U} / \mathrm{ml}$, respectively. The optimum lipase activity was found at $\mathrm{pH} 7.0,30^{\circ} \mathrm{C}$ and using methanol or ethanol in the reaction tube. Lipase was more stable at $20-30^{\circ} \mathrm{C}$ and maintained $85 \%$ of its activity. It was concluded that isolate Ms.11 is a potential source of lipase that catalyzes transesterification reactions. Further studies are required to optimize lipase production to make the strain suitable for industry purposes.
\end{abstract}

Keywords: Filamentous fungi, internal transcribed spacer, lipase, non-dairy creamer

\section{Introduction}

Lipase (triacylglycerol acyl hydrolase, E.C. 3.1.1.3) is an enzyme that catalyzes the hydrolysis and synthesis of triglycerides and other water-insoluble esters [1]. Lipase naturally hydrolyzes ester bonds at triglycerides in the presence of excess water. Besides that, lipase can catalyze the esterification reaction of fatty acids with alcohol when water concentration in the environment is low $[2,3]$. In addition to the hydrolysis and esterification reactions, lipases are also able to catalyze the transesterification reaction converting triglycerides and alcohol into fatty acid alkyl esters and glycerol as the end prod-

\section{*Corresponding author}

Tel: +6281392709667

E-mail: m.ilmi@ugm.ac.id

○ 2020, The Korean Society for Microbiology and Biotechnology ucts. Transesterification reaction is used in biodiesel synthesis [4].

Lipases can be produced by plants, animals, and microorganisms [5, 6]. Microbes, e.g. bacteria and fungi, are the most potential sources of lipase used in industry [1]. Fungal lipases gained significant attention in the industries due to their substrate specificity and stability under varied chemical and physical conditions. For instance, fungal lipase from Alternaria brassicicola was potential for detergent industry due to its optimum hydrolysis activity at $\mathrm{pH} 9$ and temperature $25^{\circ} \mathrm{C}$ [7]. Furthermore, fungal enzymes are produced extracellular so can be extracted easily, which significantly reduces the cost and makes this source preferable over bacteria [8].

Lipase-producing filamentous fungi can be obtained from soil [6], sea water [9], and oil mill wastes [8]. 
Industrial waste that uses vegetable oil as raw material can also be a source of lipase-producing filamentous fungi. Aspergillus fumigatus, Aspergillus terreus, and Penicillium sp. were lipase producers found from olive oil industrial waste [10] while species of Aspergillus, Penicillium, Trichoderma and Mucor were obtained from palm oil industrial wastes [11]. Aspergillus is one of genus that contains many lipase producing species [12].

Non-dairy creamer is creamer commonly used as flavor enhancers for drinks, such as coffee and generally made from coconut oil and palm oil [13]. PT. Kievit Indonesia is producer of non-dairy creamer and its industrial waste is assumed still containing lipid which is potential source of fungi that secret lipase. However, study on lipase-producing filamentous fungi from nondairy creamer industrial waste has never been done. The purpose of this study is to obtain lipase-producing filamentous fungi from non-dairy creamer industrial waste. Here, we screened lipase producer of fungi from non-dairy creamer industrial waste with qualitative and quantitative approaches. Then we did molecular identification of the potential isolate. Further, lipase production profile and enzyme characterization were determined.

\section{Materials and Methods}

\section{Sample collection}

Sample was obtained from PT. Kievit Indonesia, Salatiga, Central Java, Indonesia. The sample was collected using sterile plastic bags and brought to laboratory using cool box. The sample was stored at $4^{\circ} \mathrm{C}$ prior to isolation step.

\section{Isolation of filamentous fungi}

Medium used in this isolation was Mineral Salt Agar (MSA) and Potato Dextrose Agar (PDA). Mineral salt agar was modified from previous study [11]. The medium contained virgin olive oil $(10 \mathrm{ml} / \mathrm{l})$, Tween 80 (1 ml/l), $\left(\mathrm{NH}_{4}\right)_{2} \mathrm{SO}_{4}(5 \mathrm{~g} / \mathrm{l}), \mathrm{Na}_{2} \mathrm{HPO}_{4}(6 \mathrm{~g} / \mathrm{l}), \mathrm{KH}_{2} \mathrm{PO}_{4}$ (2 g/l), $\mathrm{MgSO}_{4}(3 \mathrm{~g} / \mathrm{l}), \mathrm{CaCl}_{2}(3 \mathrm{~g} / \mathrm{l})$ and $\operatorname{agar}(20 \mathrm{~g} / \mathrm{l})$. PDA was prepared by dissolving $3.9 \mathrm{~g}$ PDA (Merck, Germany) in $100 \mathrm{ml}$ distilled water. Both media were sterilized by autoclave at $1 \mathrm{~atm}, 121^{\circ} \mathrm{C}$ for $15 \mathrm{~min}$.

Ten gram solid sample was suspended in $90 \mathrm{ml}$ sterile water and the solution was shaken for 30 sec. Supernatant $(100 \mu \mathrm{l})$ was spread on media and incubated at room temperature for 5 days. Grown fungi colonies were purified by streaking on PDA plate and incubated at room temperature for 3 days. Then, every single colony formed was transferred into PDA slant and stored in low temperature. Isolates from MSA and PDA media were labeled with $\mathrm{Ms}$ and $\mathrm{Pd}$, respectively.

\section{Screening of lipase-producing filamentous fungi}

Qualitative screening. Medium used in this screening was phenol-red agar modified from previous study [14]. The medium contained phenol red $(0.04 \% \mathrm{w} / \mathrm{v})$, olive oil (0.1\% v/v), Tween 80 (0.1\% v/v), $\mathrm{CaCl}_{2}(0.1 \% \mathrm{w} / \mathrm{v})$, and agar $(2 \% \mathrm{w} / \mathrm{v})$. The $\mathrm{pH}$ was adjusted to 7 using $\mathrm{NaOH}$ $1 \mathrm{~N}$. The medium was sterilized by autoclave at $1 \mathrm{~atm}$, $121^{\circ} \mathrm{C}$ for $15 \mathrm{~min}$.

Isolates were inoculated to medium on petri dish and incubated at room temperature for 3 days. All experiments were done in triplicate. Plates were analyzed after incubation. The color change of medium from red to yellow was used as an indicator of lipase activity. The potency of the isolates for enzyme production was determined based on lypolytic index measured with the following equation [15]:

$$
\text { Lypolytic index }=\frac{\text { Diameter of yellow zone }(\mathrm{mm})}{\text { Diameter of colony }(\mathrm{mm})}
$$

Quantitative screening. Two strains with the highest lypolytic index from previous screening were used for lipase production. Lipase was produced by Submerged Fermentation (SmF) using medium based on Adham and Ahmed [16]. The medium consisted of peptone 3\%, $\mathrm{MgSO}_{4.7} \mathrm{H}_{2} \mathrm{O} 0.05 \%, \mathrm{KCl} 0.05 \%, \mathrm{~K}_{2} \mathrm{HPO} 40.2 \%$, olive oil $0.5 \%$ and glucose $0.5 \%$. Fifty ml medium was placed in $250 \mathrm{ml}$ flask sterilized by autoclave at $1 \mathrm{~atm}, 121^{\circ} \mathrm{C}$ for $15 \mathrm{~min}$.

The sterile media in Erlenmeyer flasks were inoculated with spore or hypha suspension until final concentration reached $10^{6} \mathrm{CFU} / \mathrm{ml}$ [17]. Each isolate inoculated into 4 flasks. The flasks were incubated at room temperature with $200 \mathrm{rpm}$ shaking for $96 \mathrm{~h}$. Every $24 \mathrm{~h}, 1$ flask of each isolate was filtered using a pre-weighted filter paper. The obtained biomass on filter paper was washed with distilled water prior to drying in oven at $70^{\circ} \mathrm{C}$ for $24 \mathrm{~h}$. After $24 \mathrm{~h}$, the weight of biomass was determined. The filtrate was stored at $4^{\circ} \mathrm{C}$ for lipase activity assay. All experiments were done in triplicate. 


\section{Lipase activity assay}

Esterification activity of lipase was assayed based on colorimetric method [18]. One hundred $\mu \mathrm{l}$ of filtrate was mixed with $1 \mathrm{ml}$ substrate $(0.5 \mathrm{M}$ oleic acid and $0.5 \mathrm{M}$ ethanol in isooctane) for $20 \mathrm{~min}$ at $30^{\circ} \mathrm{C}$. The reaction was stopped by placing the mixture in the ice bath for $5 \mathrm{~min}$. One hundred $\mu \mathrm{l}$ of sample from top layer (organic phase) of previous mixture was then added to $1900 \mu \mathrm{l}$ isooctane and $400 \mu \mathrm{l}$ Cupric-Acetate Pyridine (CAP) reagent. The mixture was homogenized with vortex for $5 \mathrm{sec}$ and allowed to stand for $20 \mathrm{~min}$ until the aqueous phase (bottom layer) and organic phase (top layer) separated. Absorbance value of the organic phase was then measured at $\lambda=715 \mathrm{~nm}$. One unit of esterification activity (U) is defined as the amount of oleic acid $(\mu \mathrm{mol} / \mathrm{ml})$ that is converted to products per minute [19].

\section{Molecular Identification}

The molecular identification was carried out on isolate that produced the highest lipase amount. The selected isolate was grown in $30 \mathrm{ml}$ Potato Dextrose Broth (PDB) incubated at $30^{\circ} \mathrm{C}, 48 \mathrm{~h}, 200 \mathrm{rpm}$ shaking. The mycelia were harvested by centrifugation at $4000 \mathrm{rpm}$ for $10 \mathrm{~min}$. The genomic deoxyribonucleic acid (gDNA) was isolated from the mycelia using Zymo Research Kit (Zymo Research Corporation, USA) according to the manufacturer's instructions. Then, the purity of gDNA was measured by spectrophotometry method at $\lambda 260$ / 280 using Nanodrop (Maestrogen, Taiwan).

The ITS region of ribosomal DNA was amplified using primer ITS1 (5'-TCC GTA GGT GAA CCT GCG G-3') as forward primer and ITS4 (5'-TCC TCC GCT TAT TGA TAT GC-3') as reverse primer. The PCR reaction volume was $50 \mu \mathrm{l}$ containing $25 \mu \mathrm{l}$ Mix PCR Go Taq, $20 \mu \mathrm{l}$ Nuclease-free water, $3 \mu \mathrm{l}$ gDNA, $1 \mu \mathrm{l}$ forward primer and $1 \mu \mathrm{l}$ reverse primer. Steps of PCR were initial denaturation (95 ${ }^{\circ} \mathrm{C}$ for $\left.5 \mathrm{~min}\right)$, denaturation $\left(95^{\circ} \mathrm{C}\right.$ for $\left.30 \mathrm{sec}\right)$, annealing $\left(55^{\circ} \mathrm{C}\right.$ for $\left.1 \mathrm{~min}\right)$, extension $\left(72^{\circ} \mathrm{C}\right.$ for $\left.1 \mathrm{~min}\right)$ and final extension $\left(72^{\circ} \mathrm{C}\right.$ for $\left.6 \mathrm{~min}\right)$ [9]. Denaturation, annealing and extension were done in 35 cycles using thermocycler PCR (Biorad, Germany).

The PCR product $(3 \mu \mathrm{l})$ was subjected to $1 \%$ agarose gel electrophoresis, run at $110 \mathrm{~V}$ in TBE buffer for $30 \mathrm{~min}$. The gel was mixed with SYBR Safe dye and the band at gel was visualized using UV Transilliuminator (Maestrogen, Taiwan). The size of the band was esti- mated using DNA marker AccuBand ${ }^{\mathrm{TM}} 100 \mathrm{bp}+3 \mathrm{~K}$ DNA Ladder II. Then, the PCR product was sequenced by $1^{\text {st }}$ Base Asia, Malaysia.

The consensus sequence was obtained from forward and reverse sequences that were edited with GeneStudio ${ }^{\text {TM }}$ Pro. Then, the sequence was analyzed with Basic Local Alignment Search Tool (BLAST) at www.ncbi.nih.gov to determine its similarity with references found in GenBank database. Ten strains from GenBank with the highest similarity were selected for tree reconstruction. The nucleotides were aligned with ClustalW in software Molecular Evolution Genetic Analysis version 6 (MEGA 6). The genetic distance was determined using Tamura 3-Parameter. Then, the phylogenetic tree was reconstructed based on Neighbour-Joining method with bootstrap value of 1000 (replication).

\section{Lipase production profile}

The profile of lipase production was carried out on isolate that produced the highest lipase amount. The lipase was produced by Submerged Fermentation (SmF) on different carbon source, $\mathrm{pH}$, temperature, and incubation period. All experiments were done in triplicate.

Effect of carbon source on lipase production. Medium used in this production was modified medium from Adham and Ahmed [16]. Fifty ml medium consisting of peptone $3 \%, \mathrm{MgSO}_{4 \cdot 7} \mathrm{H}_{2} \mathrm{O} 0.05 \%, \mathrm{KCl} 0.05 \%, \mathrm{~K}_{2} \mathrm{HPO} 4$ $0.2 \%$. Glucose $2 \%$, olive oil $2 \%$, and olive oil $1 \%+$ glucose $1 \%$ were supplemented separately to the medium. The sterile media were inoculated with spore suspension until final concentration reached $10^{6}$ spores $/ \mathrm{ml}$ and incubated at room temperature with $200 \mathrm{rpm}$ shaking for $96 \mathrm{~h}$. Then, biomass and lipase activity were determined.

Effect of pH on lipase production. Fifty $\mathrm{ml}$ medium with optimum carbon source was used for this step. The $\mathrm{pH}$ of medium was adjusted to 4-9 using $\mathrm{NaOH}$ and HCL. The sterile media were inoculated with spore suspension until final concentration reached $10^{6} \mathrm{spores} / \mathrm{ml}$ and incubated at room temperature with $200 \mathrm{rpm}$ shaking for $96 \mathrm{~h}$. Then, biomass and lipase activity were determined.

Effect of temperature on lipase production. Fifty $\mathrm{ml}$ medium with optimum carbon source and $\mathrm{pH}$ was used 
in this step. The sterile media were inoculated with spore suspension until final concentration reached $10^{6}$ spores $/ \mathrm{ml}$ and incubated at $25-40^{\circ} \mathrm{C}$ with $200 \mathrm{rpm}$ shaking for $96 \mathrm{~h}$.

Effect of incubation period on lipase production. Fifty $\mathrm{ml}$ medium with optimum carbon source and $\mathrm{pH}$ was used in this step. The sterile media were inoculated with spore suspension until final concentration reached $10^{6}$ spores/ml and incubated at optimum temperature with $200 \mathrm{rpm}$ shaking for 168 h. Every 24 h, biomass and lipase activity were determined.

\section{Enzyme characterization}

Lipase from isolate that produced the highest lipase amount was characterized its activity and stability. Partial purification was done prior to enzyme characterization to obtain higher purity of enzyme [20].

Partial purification. Partially purified enzyme was obtained by precipitation using ammonium sulphate with $50 \%$ of saturation. Solid ammonium sulphate (37.66 g) was added to $120 \mathrm{ml}$ crude extract enzyme at $20^{\circ} \mathrm{C}$ and allowed to stand for $48 \mathrm{~h}$ at $4^{\circ} \mathrm{C}$. The precipitate was obtained by centrifugation at $4000 \mathrm{rpm}$ for $10 \mathrm{~min}$ at $4{ }^{\circ} \mathrm{C}$. The precipitate was resuspended with a minimal amount of distilled $\mathrm{H}_{2} \mathrm{O}$ and dialyzed against distilled water using a successive large volume of $\mathrm{H}_{2} \mathrm{O}$ [16]. The total activity of precipitate and dialysate was assayed using previously described methods while the total protein was determined using Lowry method [21].

Effect of pH and temperature on lipase activity. The effect of $\mathrm{pH}$ on lipase activity was measured at various $\mathrm{pH}$ ranging from 3 to 10 . The $\mathrm{pH}$ of the enzyme suspension was varied using different buffers (citrate buffer for $\mathrm{pH}=3-6$, phosphate buffer for $\mathrm{pH}=6-8$ and borate buffer for $\mathrm{pH}=7-9$ ). The effect of temperature on lipase activity was carried out at $20,25,30,35$ and $40^{\circ} \mathrm{C}$. The enzyme assay was performed as described earlier to determine the optimum $\mathrm{pH}$ and temperature.

Effect of alcohol on lipase activity. The effect of alcohol on lipase activity was performed using methanol, ethanol and n-butanol as substrate. The concentration ratio of oleic acid and alcohol was $0.5 \mathrm{M}$ to $0.5 \mathrm{M}$. The lipase activity was assayed at optimum $\mathrm{pH}$ and temperature.

Effect of temperature on lipase stability. Enzyme solution was incubated at $20,25,30,35$, and $40^{\circ} \mathrm{C}$ for $1 \mathrm{~h}$. The remaining enzyme activity was then determined and compared with the control without incubation.

\section{Statistical analysis}

The data of lipase production and enzyme characterization were analyzed by One-Way Analysis of Varian (ANOVA) and followed by Duncan's Multiple Range Test (DMRT) with $p<0.05$ using software SPSS Statistics version 20 (IBM, USA).

\section{Results}

\section{Lipase-producing filamentous fungi}

Nineteen filamentous fungi were obtained from nondairy creamer industrial waste. Isolates have been purified on PDA media. The fungi were screened with phenol red agar medium that contains lipid as a carbon and energy source for fungi. Color change of medium indicates lipase activity. Lipase will hydrolyze lipid to fatty acids which alter $\mathrm{pH}$ medium from neutral (red) to acid (yellow) [14]. Five of nineteen isolates form yellow zone on phenol red medium. Among those 5 isolates, Ms.11 and Pd. 8 show the highest lipolytic index, $1.44 \pm 0.007$ and $1.20 \pm 0.015$, respectively (Table 1) and selected for quantitative screening.

\section{Quantitative screening of lipase-producing filamentous fungi}

Lipases of isolates Ms.11 and Pd.8 were produced by submerged fermentation using medium containing $0.5 \%$ olive oil and $0.5 \%$ glucose. The lipase productivities were observed every $24 \mathrm{~h}$ for $96 \mathrm{~h}$. The result shows that lipase activity of Ms.11 (3.76 $\pm 0.20 \mathrm{U} / \mathrm{ml})$ is higher than

Table 1. Lipolytic index of lipase-producing fungi.

\begin{tabular}{ccc}
\hline No. & Isolate & Lipolytic Index \\
\hline 1 & Ms. 2 & $1.15 \pm 0.141$ \\
2 & Ms. 8 & $1 \pm 0$ \\
3 & Ms.11 & $1.44 \pm 0.007$ \\
4 & Pd. 4 & $1.17 \pm 0.166$ \\
5 & Pd. 8 & $1.20 \pm 0.015$ \\
\hline
\end{tabular}


Table 2. Lipase activity and biomass of Ms.11 and Pd.8.

\begin{tabular}{|c|c|c|c|c|c|c|}
\hline \multirow[b]{2}{*}{ Incubation (h) } & \multicolumn{3}{|c|}{ Ms.11 } & \multicolumn{3}{|c|}{ Pd. 8} \\
\hline & $\begin{array}{l}\text { Lipase activity } \\
(\mathrm{U} / \mathrm{ml})\end{array}$ & $\begin{array}{l}\text { Biomass } \\
(\mathrm{mg} / \mathrm{ml})\end{array}$ & $\begin{array}{l}\text { Lipase production } \\
\text { (U/mg biomass) }\end{array}$ & $\begin{array}{l}\text { Lipase activity } \\
(\mathrm{U} / \mathrm{ml})\end{array}$ & $\begin{array}{l}\text { Biomass } \\
(\mathrm{mg} / \mathrm{ml})\end{array}$ & $\begin{array}{l}\text { Lipase production } \\
\text { (U/mg biomass) }\end{array}$ \\
\hline 24 & $1.56 \pm 0.34$ & $5.80 \pm 0.92$ & $0.27 \pm 0.02$ & $1.15 \pm 0.12$ & $5.67 \pm 0.31$ & $0.20 \pm 0.01$ \\
\hline 48 & $2.47 \pm 0.20$ & $8.07 \pm 0.64$ & $0.31 \pm 0.02$ & $2.23 \pm 0.27$ & $11.87 \pm 0.99$ & $0.19 \pm 0.01$ \\
\hline 72 & $3.40 \pm 0.52$ & $9.53 \pm 0.95$ & $0.36 \pm 0.03$ & $2.43 \pm 0.34$ & $9.80 \pm 1.56$ & $0.25 \pm 0.05$ \\
\hline 96 & $3.76 \pm 0.20$ & $8.60 \pm 0.80$ & $0.44 \pm 0.03$ & $3.36 \pm 0.84$ & $8.73 \pm 1.10$ & $0.38 \pm 0.05$ \\
\hline
\end{tabular}

Pd.8 (3.36 $\pm 0.84 \mathrm{U} / \mathrm{ml})$ after $96 \mathrm{~h}$ incubation (Table 2). Moreover, Ms.11 and Pd.8 have maximum lipase production, $0.44 \pm 0.03$ and $0.38 \pm 0.05 \mathrm{U} / \mathrm{mg}$ biomass, respectively. Statistical analysis showed that lipase production of Ms.11 at $96 \mathrm{~h}$ incubation gave a significantly high result when compared with $\mathrm{Pd} .8(p<0.05)$. Based on these findings, Ms.11 was selected for morphological observation, molecular identification and lipase production profile.

\section{Identification of filamentous fungi}

Molecular identification of isolate Ms.11 is based on sequence of ITS region using ITS1 and ITS4 primers. Electrophoresis of PCR product showed that the length of amplified ITS1-5,8SSU-ITS2 region is 500-600 bp (Fig. 1). BLAST analysis indicates that Ms.11 has high similarity to Aspergillus sp. 2011.9 and strains of Aspergillus aculeatus group (Table 3). Phylogenetic tree with Neighbour-Joining algoritma shows that Ms.11 has close genetic relationship to $A$. aculeatus $\mathrm{B}$ and $A$. aculeatus NFML CH59 131 (Fig. 2). Aspergillus niger ATCC 16888 was selected as an outgroup. Identical species based on the results of the BLAST analysis must have a query coverage value $\geq 80 \%$ and sequence simi-

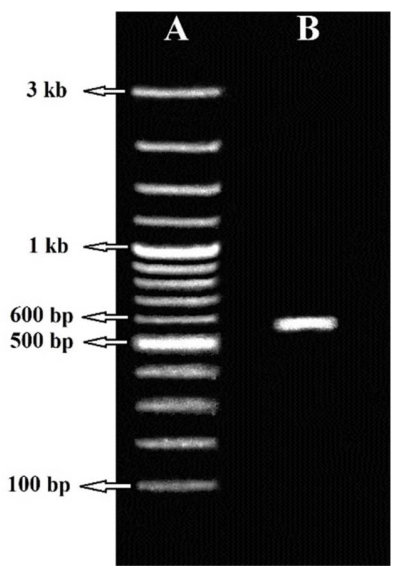

Fig. 1. Electrophoresis of PCR product of Ms.11 ITS region. (A) Marker (B) Amplicon 549 bp.

larity value $\geq 97-100 \%$ [22]. Ms.11 has query coverage $\geq 99 \%$ and similarity $>98 \%$ to all strains in the phylogenetic tree. Based on these findings, Ms.11 is considered as a member of species Aspergillus aculeatus.

\section{Lipase production}

Effect of carbon source on lipase production. The effect of carbon source on the lipase production of Ms.11 was tested using glucose $2 \%$, olive oil $2 \%$, and olive oil $1 \%+$

Table 3. BLAST analysis of Ms.11 with its closest species.

\begin{tabular}{clccc}
\hline No & \multicolumn{1}{c}{ Strain } & Query cover (\%) & Similarity (\%) & Accession number \\
\hline 1 & Aspergillus sp. 2011.9 & 99 & 99.14 & KP668958.1 \\
2 & A. aculeatus KUASN10 & 99 & 99.14 & MN186997.1 \\
3 & A. aculeatus CEP4 & 99 & 99.14 & MN173148.1 \\
4 & A. aculeatus NFML CH59 131 & 99 & 99.14 & KM458836.1 \\
5 & A. aculeatus Z2 & 99 & 98.97 & MH892845.1 \\
6 & A. aculeatus B & 100 & 98.81 & MK788185.1 \\
7 & A. aculeatus Ekm II & 99 & 98.97 & MF151167.1 \\
8 & A. aculeatus F027 & 99 & 98.97 & MN088378.1 \\
9 & A. aculeatus KUASN14 & 99 & 98.97 & MN187974.1 \\
10 & A. aculeatus aay1 & 99 & 99.31 & KY315561.1 \\
\hline
\end{tabular}




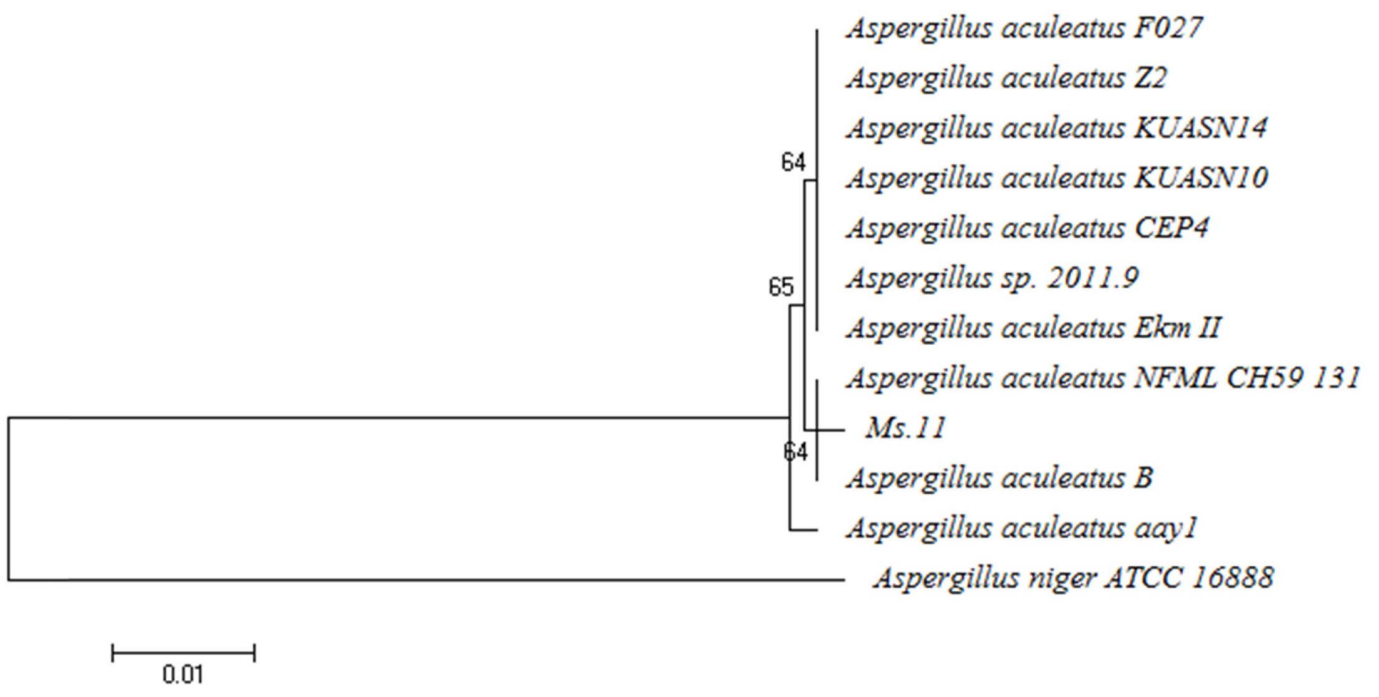

Fig. 2. Phylogenetic tree of isolate Ms.11 using MEGA 6 program with Neighbor-Joining method and 1000 replication (bootstrap).

glucose $1 \%$. The culture incubated with $200 \mathrm{rpm}$ shaking at room temperature for $96 \mathrm{~h}$. Lipase activity (U/ml), biomass $(\mathrm{mg} / \mathrm{ml}$ ) and lipase production (U/mg biomass) can be seen in Fig. 3. The result shows that the highest lipase activity of Ms.11 $(4.74 \pm 1.42 \mathrm{U} / \mathrm{ml})$ is produced in medium of olive oil $1 \%+$ glucose $1 \%$, while growth in glucose $2 \%$ produces the lowest lipase activity $(0.85 \pm$ $0.28 \mathrm{U} / \mathrm{ml})$. Based on the ratio between lipase activity and biomass among the tested carbon source, medium containing olive oil $1 \%+$ glucose $1 \%$ gives the highest lipase production $(0.37 \pm 0.03 \mathrm{U} / \mathrm{mg}$ biomass $)$ and significantly different $(p<0.05)$ to other carbon sources.

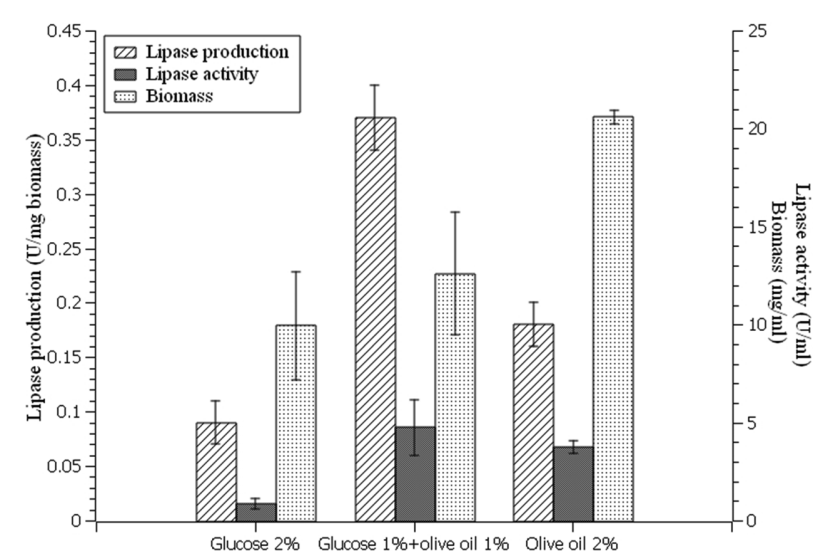

Fig. 3. Lipase activity, biomass, and lipase production of Ms.11 on different carbon source. Incubation at room temperature for $96 \mathrm{~h}$ with $200 \mathrm{rpm}$ shaking.
Effect of $\mathbf{p H}$ on lipase production. The effect of $\mathrm{pH}$ on the lipase production of Ms.11 was tested using medium containing olive oil $1 \%+$ glucose $1 \%$ at $\mathrm{pH} 4-9$. The culture incubated with $200 \mathrm{rpm}$ shaking at room temperature for $96 \mathrm{~h}$. Lipase activity (U/ml), biomass (mg/ $\mathrm{ml}$ ) and lipase production (U/mg biomass) can be seen in Fig. 4. The result shows that high lipase activity was found in slightly acidic conditions to neutral. Ms.11 produces high lipase activity at $\mathrm{pH} 6$ and 7, $4.59 \pm 0.17 \mathrm{U} / \mathrm{ml}$ and $4.83 \pm 0.62 \mathrm{U} / \mathrm{ml}$, respectively. Based on ratio between lipase activity and biomass, lipase production at $\mathrm{pH} 7$ gives the highest productivity $(0.43 \pm 0.03 \mathrm{U} / \mathrm{mg}$

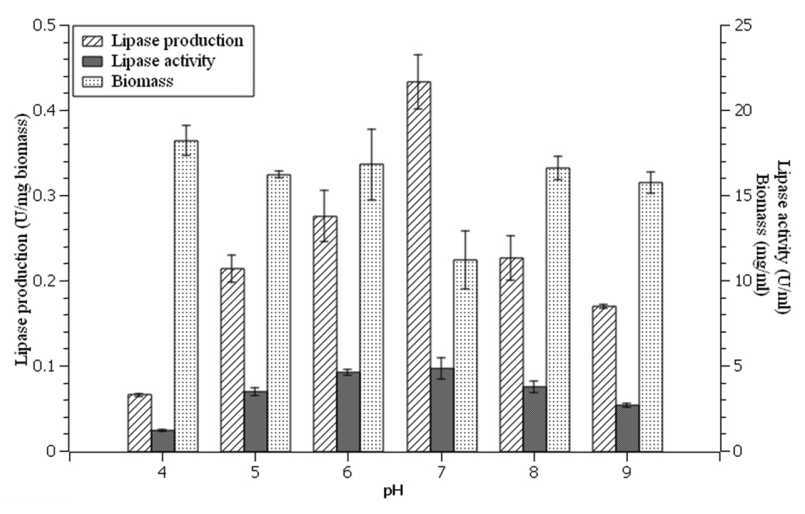

Fig. 4. Lipase activity, biomass, and lipase production of Ms. 11 at different $\mathrm{pH}$ using medium containing olive oil $1 \%$ + glucose 1\%. Incubation at room temperature for $96 \mathrm{~h}$ with 200 rpm shaking. 


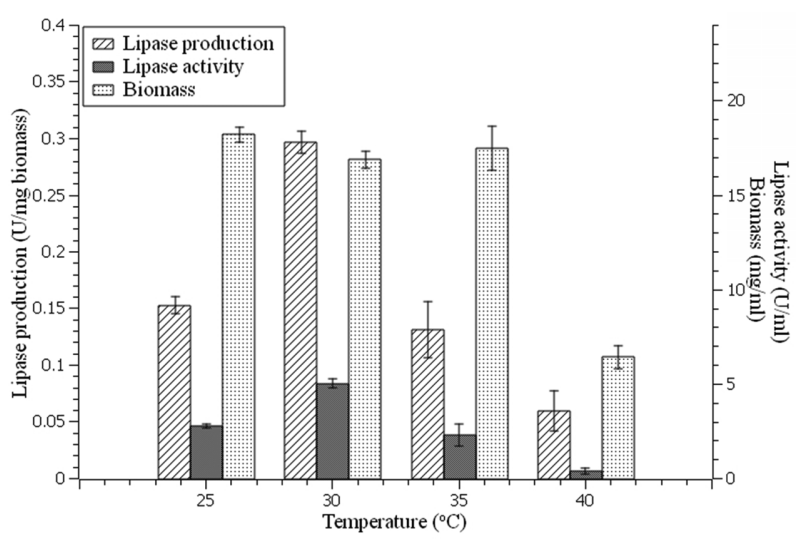

Fig. 5. Lipase activity, biomass, and lipase production of Ms.11 at different temperature using medium containing olive oil $1 \%+$ glucose $1 \%$ at pH 7 and $96 \mathrm{~h}$ incubation time with 200 rpm shaking.

biomass) and significantly different $(p<0.05)$ with other $\mathrm{pH}$. The production in other $\mathrm{pH}$ gave much lower results.

Effect of temperature on lipase production. The effect of temperature on the lipase production of Ms.11 was tested using medium containing olive oil $1 \%+$ glucose $1 \%$ which was adjusted to $\mathrm{pH} 7$. The culture incubated with $200 \mathrm{rpm}$ agitation at $25-40^{\circ} \mathrm{C}$ for $96 \mathrm{~h}$. Lipase activity $(\mathrm{U} / \mathrm{ml})$, biomass $(\mathrm{mg} / \mathrm{ml})$ and lipase production (U/mg biomass) can be seen in Fig. 5. Among the tested temperatures, Ms.11 produces the highest lipase activity at $30^{\circ} \mathrm{C}(5.00 \pm 0.25 \mathrm{U} / \mathrm{ml})$ while $40^{\circ} \mathrm{C}$ gave the lowest activity $(0.39 \pm 0.15 \mathrm{U} / \mathrm{ml})$. Furthermore, Fig. 5 shows that optimum lipase production $0.30 \pm 0.01 \mathrm{U} / \mathrm{mg}$ biomass) was found at $30^{\circ} \mathrm{C}$ and significantly different $(p<0.05)$ with other temperatures.

Effect of incubation period on lipase production. The effect of incubation period on the lipase production of Ms.11 was tested using medium containing olive oil 1\% + glucose $1 \%$ which was adjusted to $\mathrm{pH} 7$. The culture incubated with $200 \mathrm{rpm}$ shaking at $30^{\circ} \mathrm{C}$ for $168 \mathrm{~h}$. Biomass and lipase activity were determined every $24 \mathrm{~h}$. Fig. 6 shows that high lipase activity was produced after incubation for 96 and $120 \mathrm{~h}, 5.13 \pm 0.30 \mathrm{U} / \mathrm{ml}$ and $5.22 \pm 0.59 \mathrm{U} / \mathrm{ml}$, respectively. Optimum lipase production ( $0.31 \pm 0.02 \mathrm{U} / \mathrm{mg}$ biomass) was found after $96 \mathrm{~h}$ and stable until $120 \mathrm{~h}(0.30 \pm 0.04 \mathrm{U} / \mathrm{mg}$ biomass $)$. After

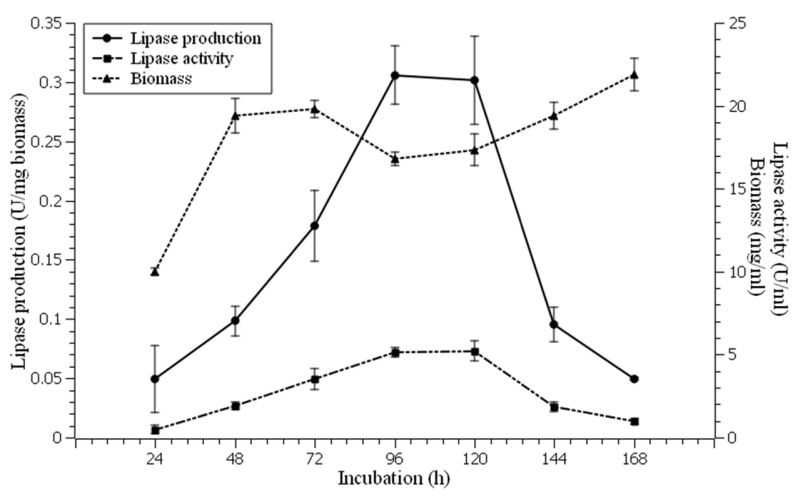

Fig. 6. Lipase activity, biomass, and lipase production of Ms.11 using medium containing olive oil $1 \%+$ glucose $1 \%$ at pH 7. Incubation at $30^{\circ} \mathrm{C}$ with $200 \mathrm{rpm}$ shakingfor $168 \mathrm{~h}$ and harvested every $24 \mathrm{~h}$.

$120 \mathrm{~h}$ incubation period, lipase production begins to decrease until $168 \mathrm{~h}$ of incubation period $(0.05 \pm 0.001 \mathrm{U} /$ $\mathrm{mg}$ biomass) due to the decline of lipase activity and the increase of biomass.

\section{Enzyme characterization}

Effect of $\mathrm{pH}$ on lipase activity. The effect of $\mathrm{pH}$ on lipase activity was measured at various $\mathrm{pH}$ of solution enzyme ranging from 3 to 9 . Fig. 7 shows that lipase tends to be active under slightly acidic conditions to neutral. Optimum lipase activity $(7.09 \pm 0.61 \mathrm{U} / \mathrm{mg}$ protein) was found at $\mathrm{pH} 7$ using phosphate buffer and significantly different $(p<0.05)$ with other $\mathrm{pH}$.

Effect of temperature on lipase activity. The effect of

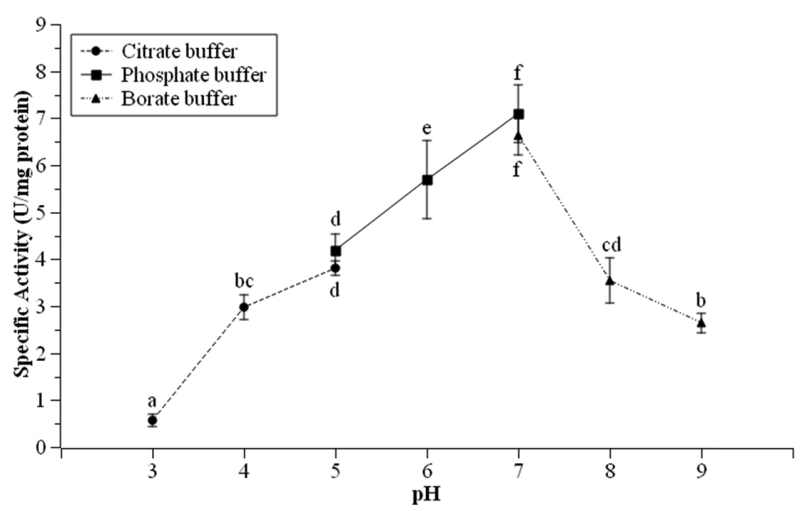

Fig. 7. Activity of Ms. 11 lipase at various reaction $\mathrm{pH}$. The $\mathrm{pH}$ of enzyme solution was adjusted using different buffers (citrate buffer for $\mathrm{pH}=3-5$, phosphate buffer for $\mathrm{pH}=5-7$ and borate buffer for $\mathrm{pH}=7-9$ ). Same letters indicate not significantly different according to Duncan's test $(\alpha=0.05)$. 


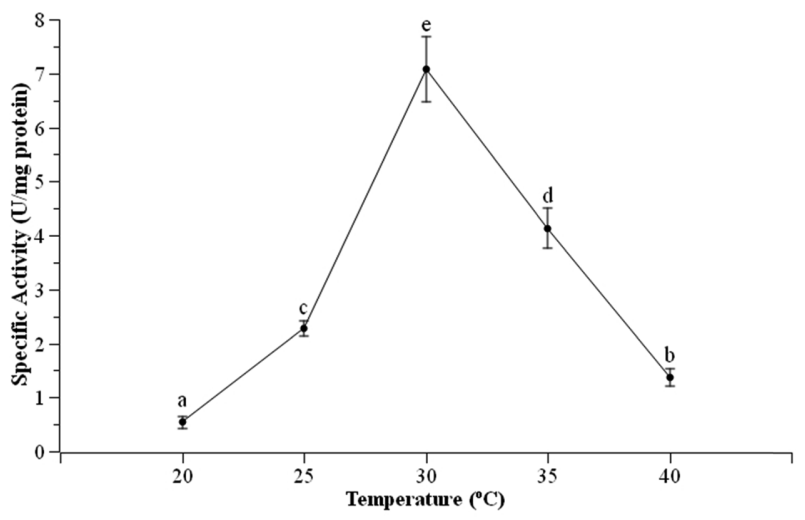

Fig. 8. Ms. 11 lipase activity at various temperatures (20, $25,30,35$ and $40{ }^{\circ} \mathrm{C}$ ). The reaction using phosphate buffer $\mathrm{pH}$ 7 as enzyme solution. Same letters indicate not significantly different according to Duncan's test $(\alpha=0.05)$.

temperatures was determined by assaying lipase activity at different temperatures $\left(20-40^{\circ} \mathrm{C}\right)$. The $\mathrm{pH}$ of enzyme solution was 7 using phosphate buffer. Optimum lipase activity was found at $30^{\circ} \mathrm{C}$ and significantly different $(p<0.05)$ with other temperatures. Fig. 8 shows that lipase activity increases at reaction temperature 20 to $30^{\circ} \mathrm{C}$ and then decreases until the temperature reach $40^{\circ} \mathrm{C}(1.37 \pm 0.16 \mathrm{U} / \mathrm{mg})$. Optimum activity of lipase from Ms. 11 occurs at $30^{\circ} \mathrm{C}$ corresponds to optimum lipase production at $30^{\circ} \mathrm{C}$.

Effect of alcohol on lipase activity. The effect of alcohol on lipase activity was performed by using methanol, ethanol, and n-butanol as substrates in esterification reac-

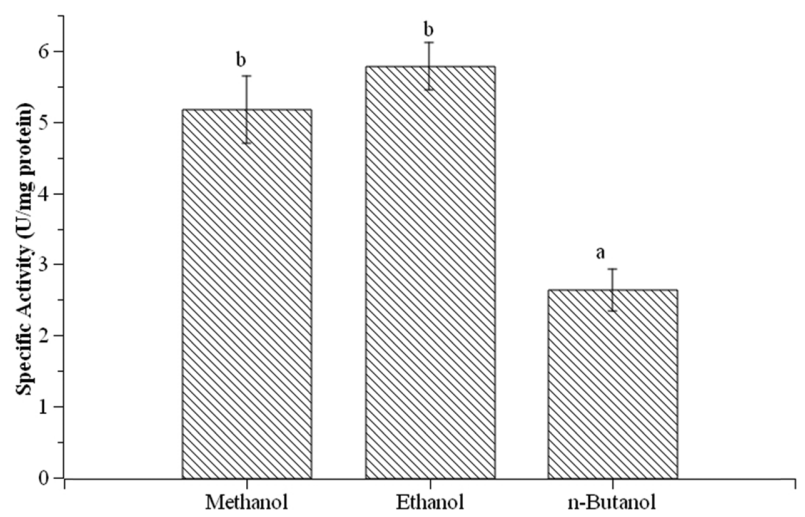

Fig. 9. Activity of Ms. 11 lipase using different alcohols as substrate (methanol, ethanol and $\mathbf{n}$-butanol). Same letters indicate not significantly different according to Duncan's test $(\alpha=0.05)$.

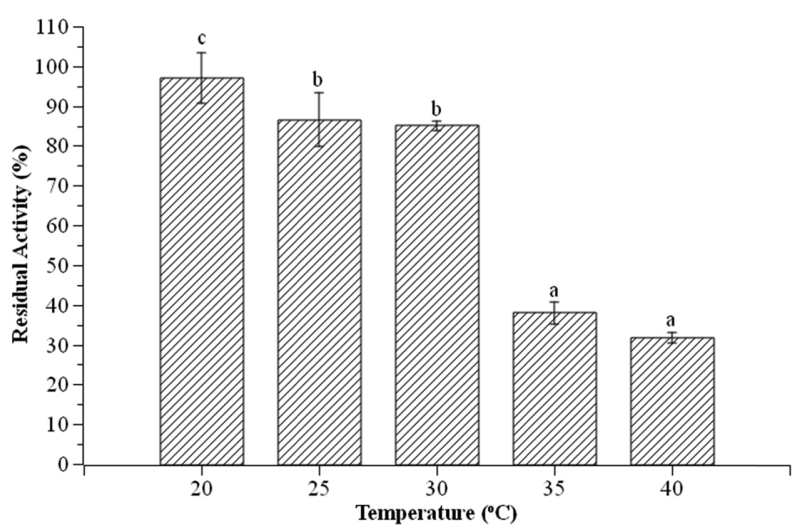

Fig. 10. Stability of Ms.11 lipase at various temperatures $\left(20,25,30,35\right.$ and $\left.40^{\circ} \mathrm{C}\right)$ with $1 \mathrm{~h}$ preincubation. The reaction was done at $30^{\circ} \mathrm{C}$ using phosphate buffer $\mathrm{pH} 7$ as enzyme solution. Same letters indicate not significantly different according to Duncan's test ( $\alpha=0.05)$.

tion. Lipase activity was assayed at optimum $\mathrm{pH}$ and temperature. Fig. 9 shows the highest to the lowest enzyme activity was found in ethanol, methanol, and nbutanol, respectively. However, methanol and ethanol have similar specific activities, $5.17 \pm 0.47$ and $5.78 \pm$ $0.33 \mathrm{U} / \mathrm{mg}$, respectively. On the other hand, lipase activity in the reaction using butanol is significantly different $(p<0.05)$ than the others.

Effect of temperature on lipase stability. The effect of temperature on lipase stability was done by incubating enzyme solution at $20-40^{\circ} \mathrm{C}$ for $1 \mathrm{~h}$. Then, lipase activity was assayed at optimum $\mathrm{pH}$ and temperature. Fig. 10 shows that lipase is able to maintain its activity $>85 \%$ after $1 \mathrm{~h}$ incubation at temperature of $20-30^{\circ} \mathrm{C}$. However, lipase can only maintain its activity $<40 \%$ after $1 \mathrm{~h}$ incubation at temperature of $35-40^{\circ} \mathrm{C}$.

\section{Discussion}

There are five lipase-producing filamentous fungi obtained from non-dairy creamer industrial waste and the highest lipase production is isolate Ms.11. Ms.11 is a member of Aspergillus aculeatus group based on molecular identification using sequence analysis of Internal Transcribed Spacer (ITS). The region of Internal Transcribed Spacer (ITS) is known as a universal DNA barcode for fungi [23] and has been determined as the main barcode for molecular identification of fungi [24]. Fur- 
thermore, the sequence variation of ITS regions has led to their use in phylogenetic studies of many different organisms [9].

Aspergillus aculeatus belongs to niger group [25]. Aspergillus aculeatus is known for its ability to produce $\beta$-glucosidase (specific activity $\geq 180 \mathrm{U} / \mathrm{mg}$ ) which is higher than other fungi [26]. Aspergillus aculeatus species is generally found in soil and the fungus can act as phosphate-solubilizing fungus [27], as well as producing several types of enzymes, such as pectinase [28], lignocellulose-degrading enzymes [29], carboxymethyl cellulase and xylanase [30]. Roy et al. [31] obtained lipaseproducing Aspergillus aculeatus from soil contaminated dairy waste with optimum hydrolysis activity of $9.51 \mathrm{U} /$ ml. However, the esterification activity of lipase from Aspergillus aculeatus has not been determined.

Aspergillus aculeatus Ms.11 produced the highest lipase production $(0.44 \pm 0.03 \mathrm{U} / \mathrm{mg}$ biomass) after $96 \mathrm{~h}$ incubation using medium containing $0.5 \%$ olive oil and $0.5 \%$ glucose. This lipase production was higher than that reported by Adham and Ahmed [16] where Aspergillus niger NRRL3 had lipase production $0.37 \mathrm{U} / \mathrm{mg}$ biomass after $96 \mathrm{~h}$ incubation using the same medium. Ms. 11 needed glucose as an initial nutrient for cell growth and would produce high amounts of lipase after glucose was depleted. Mucor griseocyanus grown on medium containing glucose and coconut oil produced the highest lipase on the 3rd day after glucose in the medium run out [32].

Increasing the concentration of carbon sources in the medium from glucose $0.5 \%+$ olive oil $0.5 \%$ to glucose $1 \%$ + olive oil $1 \%$ made the lipase production (the ratio between lipase activity $(\mathrm{U} / \mathrm{ml})$ and biomass $(\mathrm{mg} / \mathrm{ml})$ ) of Ms.11 decreased due to increased biomass. However, the increased concentration of the carbon source caused an increase in lipase activity from $3.76 \pm 0.20$ to $4.74 \pm$ $1.42 \mathrm{U} / \mathrm{ml}$. Adham and Ahmed [16] reported that an increase in carbon source from $1 \%$ glucose + olive oil to $2 \%$ glucose + olive oil can increase lipase activity of Aspergillus niger NRRL3. Moreover, lipase is inducible enzymes and generally produced in the presence of lipid as inducers, such as animal fat and vegetable oil [33]. Lipase production will increase if suitable inducer is added to the growth medium of microorganisms. Olive oil is one of the best inducers in lipase production $[12,33]$.
$\mathrm{pH}$ and temperature are abiotic factors that significantly affect the production of microbial enzymes. Berto et al. [7] stated that the optimum $\mathrm{pH}$ for lipase production was dependent on the fungal species. According to our result, maximum lipase production of Ms.11 was obtained on neutral $\mathrm{pH}$ and corresponded to El-Ghonemy et al. [34] that optimum lipase production of Curvularia $s p$. DHE 5 was found at $\mathrm{pH}$ 7. Furthermore, the result showed that lipase activity of Ms.11 in $\mathrm{pH} 7$ at room temperature $(4.83 \pm 0.62 \mathrm{U} / \mathrm{ml})$ was lower than $30^{\circ} \mathrm{C}$ $(5.00 \pm 0.25 \mathrm{U} / \mathrm{ml})$. Other filamentous fungi known to produce optimum lipase at $30^{\circ} \mathrm{C}$ were Penicillum chrysogenum [35] and Aspergillus fumigatus MTCC 9657 [36]. In addition, biomass of Ms. 11 in $\mathrm{pH} 7$ at $30^{\circ} \mathrm{C}$ also increased compared to room temperature. Temperature required for lipase production corresponds with the conditions of microorganisms growth [37]. Lipase-producing microorganisms are generally mesophilic, growing at temperatures between $25-40^{\circ} \mathrm{C}$ [38].

Ms.11 growth for $168 \mathrm{~h}$ (7 days) incubation formed diauxic curve, as a response to two types of carbon sources in the medium [39] and a form of adaptation to maximize the growth of microorganisms in a multinutrient environment [40]. In this study, glucose and olive oil were used as carbon source. The diauxic curve is a combination of two microorganism growth curves. The first curve shows the use of the first carbon source, glucose, and the second curve shows the use of the second carbon source, olive oil, after glucose has depleted. Glucose is a simpler molecule than olive oil so it can be directly absorbed by microbes as a carbon source. Fig. 6 showed the increase of biomass and lipase activity from 24 to $72 \mathrm{~h}$ of incubation. Then, biomass decreased after $96 \mathrm{~h}$ indicating a second lag phase as well as a shift to the second growth curve [40]. The highest lipase activity was found at 96 and $120 \mathrm{~h}$ of incubation which showed high olive oil utilization as a second carbon source. In addition, maximum lipase activity indicated that glucose in the medium has been used up [32].

$\mathrm{pH}$ is one of the important factors that influence enzyme activity. Enzymes have certain $\mathrm{pH}$ condition when they are most active [41]. According to our result, lipase from Ms.11 has optimum activity at $\mathrm{pH}$ 7. Ibrahim et al. [42] found that $\mathrm{pH} 7$ was the optimum condition for Humicola lanuginosa lipase activity, however, Aspergillus niger J-1 [43] and A. niger NCIM 1207 [44] had optimum 
activity under acidic conditions, $\mathrm{pH} 6$ and 3, respectively. Decreased lipase activity can occur due to denaturation processes caused by change of environmental $\mathrm{pH}$ [45]. Negative and positive charged amino acid will interact to form ionic bond (salt bridge) which is one of the supporting bonds that form tertiary structure of enzymes. Extreme $\mathrm{pH}$ will break the ionic bonds by changing amino acid charge and producing a repulsive force. This will make enzyme structure unfolded and lead to change of conformity and lack of catalytic properties of enzyme [41, 45]. Furthermore, enzyme properties correlated to its source. Optimum activity of lipase from Ms.11 occurred at neutral condition corresponded to optimum lipase production at neutral condition as well.

Temperature is also one of the important factors that influence enzyme activity. The result showed that lipase from Ms. 11 has optimum activity at $30^{\circ} \mathrm{C}$. Rajeswari et al. [35] and Pera et al. [46] reported that lipase from Penicillum chrysogenum and Aspergillus niger MYA 135 reached maximum activity at $30^{\circ} \mathrm{C}$. High temperatures will disrupt the three-dimensional structure of enzymes then enzymes are denatured and lose their catalytic properties [41]. Moreover, enzyme properties correlated to its source. Optimum activity of lipase from Ms.11 occurred at $30^{\circ} \mathrm{C}$ corresponded to optimum lipase production at $30^{\circ} \mathrm{C}$ as well.

Lipase has alcohol specificity for the best esterification result. The result showed that lipase from Ms.11 has the best result using methanol and ethanol. Lipase from Rhizomucor miehei showed the best results using butanol, whereas lipases from Thermomyces lanuginosus showed the best results using ethanol and butanol [47]. Bernardes et al. [48] and Lotti et al. [49] mentioned that lipase can catalyze transesterification reaction in biodiesel production using triglycerides and short chain alcohols, methanol and ethanol. Alcohol acts as a substrate for esterification or transesterification, however, alcohol is also a denaturing agent for protein or enzyme [50]. Low activity of lipase in n-butanol treatment might occur due to the sensitivity of the enzyme to n-butanol. Aspergillus niger MYA 135 lipase was more stable in methanol and ethanol exposure and able to maintain $100 \%$ of its enzymatic activity, while n-butanol exposure can reduce enzymatic activity up to $40 \%$ [46] and even lose all of its enzymatic activity [51].

Lipase from Ms.11 is quite susceptible to tempera- tures above $30^{\circ} \mathrm{C}$. According to the result, the lipase loses $60 \%$ of its activity after being exposed at $35-40^{\circ} \mathrm{C}$ for $1 \mathrm{~h}$. Temperature $30^{\circ} \mathrm{C}$ is the optimum lipase activity, however, exposure at $30^{\circ} \mathrm{C}$ for $1 \mathrm{~h}$ is considered hot and can damage bonds forming tertiary structure and lead to decrease activity. Adham and Ahmed [16] proved that Aspergillus niger NRRL3 lipase was able to maintain $>80 \%$ of its activity after $1 \mathrm{~h}$ incubation at temperature of $20-40^{\circ} \mathrm{C}$ and its activity decreased significantly after $1 \mathrm{~h}$ incubation at $60^{\circ} \mathrm{C}$. It indicated that each enzyme has different temperature stability which is influenced by the supporting bonds in the enzyme molecule.

We successfully obtained lipase-producing filamentous fungi from non-dairy creamer industrial waste. Isolate producing the highest amount lipase was Ms.11 which identified as Aspergillus aculeatus based on Internal Transcribe Spacer (ITS) sequence. Lipase from Ms.11 was inducible enzyme and had the best esterification reaction using short chain alcohol, methanol and ethanol, which used in biodiesel industry. Further study to assay transesterification activity using different oil as substrate is needed. Moreover, optimization of lipase production is required to make the strain suitable for lipase industry.

\section{Acknowledgments}

This study was partly supported by the RTA program of Universitas Gadjah Mada (nr. 3002/UN1/DITLIT/DIT-LIT/LT/2019). We also thank to PT. Kievit Indonesia for providing us with sample.

\section{Conflict of Interest}

The authors have no financial conflicts of interest to declare.

\section{References}

1. Abdelmonaem M, Hatem B, Imen G, Jeannette BH. 2010. Classification of EC 3.1.1.3 bacterial true lipases using phylogenetic analysis. Afr. J. Biotechnol. 9: 8243-8247.

2. Singh AK, Mukhopadhyay M. 2012. Overview of fungal lipase: A review. Appl. Biochem. Biotechnol. 166: 486-520.

3. Ponnarasy G, Khan MdMR, Kalam MdA, Mahmud MS. 2014. Light induced esterification of oleic acid catalyzed by Pseudomonas Cepacia Lipase. Int. J. Environ. Sci. Dev. 5: 344-346.

4. Hassan MHj, Kalam MdA. 2013. An Overview of biofuel as a renewable energy source: development and challenges. Procedia Eng. 56: 39-53. 
5. Gupta R, Gupta N, Rathi P. 2004. Bacterial lipases: an overview of production, purification and biochemical properties. Appl. Microbiol. Biotechnol. 64: 763-781.

6. Shreya, Sharma AK, Sharma V, Saxena J. 2018. Isolation and screening of lipolytic soil fungi. Int. J. Pharm. Biol. Sci. 8: 391-396.

7. Berto P, Belingheri L, Dehorter B. 1997. Production and purification of a novel extracellular lipase from Alternaria brassicicola. Biotechnol. Lett. 19: 533-536.

8. Gopinath SCB, Hilda A, Anbu P. 2005. Extracellular enzymatic activity profiles in fungi isolated from oil-rich environments. Mycoscience 46: 119-126.

9. Sadati R, Barghi A, Larki RA. 2015. Isolation and screening of lipolytic fungi from coastal waters of the southern caspian sea (North of Iran). Jundishapur J. Microbiol. 8: 1-7.

10. Rihani A, Tichati L, Soumati B. 2018. Isolation and identification of lipase- producing fungi from local olive oil manufacture in East of Algeria. Chem Chem. Eng. Biotechnol. Food Ind. 19: 13-22.

11. Nwuche CO, Ogbonna JC. 2011. Isolation of lipase producing fungi from palm oil Mill effluent (POME) dump sites at Nsukka. Braz. Arch Biol. Technol. 54: 113-116.

12. Sharma R, Chisti Y, Banerjee UC. 2001. Production, purification, characterization, and applications of lipases. Biotechnol. Adv. 19: 627-662.

13. Rosida DF, Mulyani T, Septalia LR. 2016. A comparative study of non-dairy cream based on the type of leguminosae protein source in terms of physico chemical properties and organoleptic. Agric. Agric. Sci. Procedia. 9: 431-439.

14. Lee LP, Karbul HM, Citartan M, Gopinath SCB, Lakshmipriya T, Tang T-H. 2015. Lipase-Secreting Bacillus Species in an oil-contaminated habitat: promising strains to alleviate oil pollution. BioMed. Res. Int. 2015: 1-9.

15. Gohel V, Singh A, Vimal M, Ashwini P. 2006. Bioprospecting and antifungal potential of chitinolytic microorganisms. Afr. J. Biotechnol. 5: 54-72.

16. Adham NZ, Ahmed EM. 2009. Extracellular lipase of Aspergillus niger NRRL3; production, partial purification and properties. Indian J. Microbiol. 49: 77-83.

17. Lima LGR, Gonçalves MMM, Couri S, Melo VF, Sant'Ana GCF, Costa ACA da. 2019. Lipase production by Aspergillus niger $C$ by submerged fermentation. Braz. Arch Biol Technol. 62: 1-14.

18. Kwon DY, Rhee JS. 1986. A simple and rapid colorimetric method for determination of free fatty acids for lipase assay. J. Am. Oil Chem. Soc. 63: 89-92.

19. IImi M, Hidayat C, Hastuti $P$, Heeres HJ, van der Maarel MJEC. 2017. Utilisation of Jatropha press cake as substrate in biomass and lipase production from Aspergillus niger 6516 and Rhizomucor miehei CBS 360.62. Biocatal. Agric. Biotechnol. 9: 103-107.

20. Arya A, Kumar A, Jha J. 2018. Understanding Enzymes: An Introductory Text. Drawing Pin Publishing, New Delhi, India.

21. Lowry OH, Rosebrough NJ, Farr AL, Randall RJ. 1951. Protein measurement with the Folin phenol reagent. J. Biol. Chem. 193: 265-276.

22. Raja HA, Miller AN, Pearce CJ, Oberlies NH. 2017. Fungal identifi- cation using molecular tools: A primer for the natural products research community. J. Nat. Prod. 80: 756-770.

23. Mahmoud AGY, Zaher EHF. 2015. Why nuclear ribosomal internal transcribed spacer (ITS) has been selected as the DNA barcode for fungi? Adv. Genet. Eng. 04: 1-2.

24. Begerow D, Nilsson H, Unterseher M, Maier W. 2010. Current state and perspectives of fungal DNA barcoding and rapid identification procedures. Appl. Microbiol. Biotechnol. 87: 99-108.

25. Silva DM, Batista LR, Rezende EF, Fungaro MHP, Sartori D, Alves E. 2011. Identification of fungi of the genus Aspergillus section nigri using polyphasic taxonomy. Braz. J. Microbiol. 42: 761-73.

26. Molina G, Contesini FJ, de Melo RR, Sato HH, Pastore GM. 2016. $\beta$ Glucosidase from Aspergillus. pp. 155-169. New and Future Developments in Microbial Biotechnology and Bioengineering.

27. Yin Z, Fan B, Roberts D, Chen S, Shi F, Buyer J, et al. 2017. Enhancement of maize growth and alteration of the rhizosphere microbial community by phosphate-solubilizing fungus Aspergillus aculeatus P93. J. Agric. Biotechnol. 2: 1-10.

28. de Oliveira RL, da Silva OS, Converti A, Porto TS. 2018. Thermodynamic and kinetic studies on pectinase extracted from Aspergillus aculeatus: Free and immobilized enzyme entrapped in alginate beads. Int. J. Biol. Macromol. 115: 1088-1093.

29. Suwannarangsee S, Arnthong J, Eurwilaichitr L, Champreda V. 2014. Production and characterization of multi-polysaccharide degrading enzymes from Aspergillus aculeatus BCC199 for saccharification of agricultural residues. J. Microbiol. Biotechnol. 24: 1427-1437.

30. Boonmee A. 2012. Hydrolysis of various thai agricultural biomasses using the crude enzyme from Aspergillus aculeatus iizuka FR60 isolated from soil. Braz. J. Microbiol. 43: 456-466.

31. Roy M, Kumar R, Ramteke A, Sit N. 2018. Identification of lipase producing fungus isolated from dairy waste contaminated soil and optimization of culture conditions for lipase production by the isolated fungus. J. Microbiol. Biotechnol. Food Sci. 8: 698-704.

32. Armas JC, Mendoza JCD, Hernández JLM. 2008. Mucor griseocyanus lipase: production, characterization and study of some catalytic properties of the Immobilized Enzyme. Food Technol. Biotechnol. 46: 195-201.

33. Silva OBW, Mitidieri S, Schrank A, Vainstein MH. 2005. Production and extraction of an extracellular lipase from the entomopathogenic fungus Metarhizium anisopliae. Process Biochem. 40: 321326.

34. El-Ghonemy DH, El-Gamal M, Tantawy AE, Ali TH. 2017. Extracellular alkaline lipase from a novel fungus Curvularia sp. DHE 5: optimization of physicochemical parameters, partial purification and characterization. Food Technol. Biotechnol. 55: 206-217.

35. Rajeswari T, Palaniswamy M, Rose BS, Shyni PM, Padmapriya B. 2011. Biosynthesis of novel alkaline lipase production from Penicillum Chrysogenum suitable for detergent formulation. Res. J. Pharm. Biol. Chem. Sci. 2: 128-141.

36. Rajan A, Nair AJ. 2011. A comparative study on alkaline lipase production by a newly isolated Aspergillus fumigatus MTCC 9657 in submerged and solid-state fermentation using economically 
and industrially feasible substrate. Turk. J. Biol. 569-574.

37. Salihu A, Alam Z. 2012. Production and applications of microbial lipases: A review. Sci. Res. Essays. 7: 2667-777.

38. Ayinla ZA, Ademakinwa AN, Agboola FK. 2017. Studies on the optimization of lipase production by Rhizopus sp. ZAC3 isolated from the contaminated soil of a palm oil processing shed. J. Appl. Biol. Biotechnol. 5: 30-37.

39. Wang X, Xia K, Yang X, Tang C. 2019. Growth strategy of microbes on mixed carbon sources. Nat. Commun. 10: 1279.

40. Chu D, Barnes DJ. 2016. The lag-phase during diauxic growth is a trade-off between fast adaptation and high growth rate. Sci. Rep. 6: 25191.

41. Robinson PK. 2015. Enzymes: principles and biotechnological applications. Essays Biochem. 59: 1-41.

42. Ibrahim CO, Hayashi M, Nagai S. 1987. Purification and some properties of a thermostable lipase from Humicola lanuginosa No. 3. Agric. Biol. Chem. 51: 37-45.

43. Falony G, Armas JC, Mendoza JCD, Hernández JLM. 2006. Production of extracellular lipase from Aspergillus niger by solid-state fermentation. Food Technol. Biotechnol. 44: 235-240.

44. Mahadik ND, Puntambekar US, Bastawde KB, Khire JM, Gokhale DV. 2002. Production of acidic lipase by Aspergillus niger in solid state fermentation. Process Biochem. 38: 715-721.

45. Kishore D, Kundu S, Kayastha AM. 2012. Thermal, chemical and
$\mathrm{pH}$ induced denaturation of a multimeric $\beta$-Galactosidase reveals multiple unfolding pathways. PLoS One. 7: e50380.

46. Pera LM, Romero CM, Baigori MD, Castro GR. 2006. Catalytic properties of lipase extracts from Aspergillus niger. Food Technol. Biotechnol. 44: 247-252.

47. Rodrigues RC, Volpato G, Wada K, Ayub MAZ. 2008. Enzymatic synthesis of biodiesel from transesterification reactions of vegetable oils and short chain alcohols. J. Am. Oil Chem. Soc. 85: 925930.

48. Bernardes OL, Bevilaqua JV, Leal MCMR, Freire DMG, Langone MAP. 2007. Biodiesel fuel production by the transesterification reaction of soybean oil using immobilized lipase. Appl. Biochem. Biotechnol. 7: 105-114.

49. Lotti M, Pleiss J, Valero F, Ferrer P. 2015. Effects of methanol on lipases: Molecular, kinetic and process issues in the production of biodiesel. Biotechnol. J. 10: 22-30.

50. Herkovits TT, Gadegbeku B, Jaillet H. 1970. On the structural stability and solvent denaturation of proteins. J. Biol. Chem. 245: 2588-2598.

51. Romero CM, Pera LM, Loto F, Vallejos C, Castro G, Baigori MD. 2012. Purification of an organic solvent-tolerant lipase from Aspergillus niger MYA 135 and its application in ester synthesis. Biocatal. Agric. Biotechnol. 1: 25-31. 